\title{
ГЕНЕТИКА
}

\section{First molecular cytogenetic characterization of the MMT 060562 murine breast cancer cell line}

\author{
Shaymaa Azawi $\oplus^{\circledR}$, Lisa-Marie Barf $\oplus^{\circ}$, Thomas Liehr \\ Jena University Hospital, Friedrich Schiller University, Institute of Human Genetics, \\ Am Klinikum 1, D-07747 Jena, Germany \\ Corresponding author: Thomas Liehr(Thomas.Liehr@med.uni-jena.de)
}

\begin{abstract}
Background: Murine cell lines are working horses applied as model systems in multiple research studies in many laboratories. Nonetheless, most of them are not well characterized at the genetic level. This diagnosis holds also true for the MMT 060562 murine breast cancer cell line, also referred to as MMT060562 or MMT060562. The aim of the study: To provide detailed cytogenetic characterization of the MMT 060562 cancer cell line. Materials and methods: The cell line was studied by molecular cytogenetics, namely by fluorescence in situ hybridization applying all murine while chromosome paints in one probe set and all chromosome-specific murine multicolor banding probe sets. Results: For this we present here the first detailed karyotype of the established in 1962 cell line, a comprehensive map of chromosomal imbalances and an in-silico translation of the results to the human genome. Surprisingly, MMT 060562 has only few chromosomal aberrations, even a cell clone without any gross chromosomal abnormalities in $\sim 40 \%$ of the cells, and with most aberrant of four cell clones showing a dicentric $\operatorname{dic}(2 ; 17)(\mathrm{A} 1 \mathrm{~A} 1)$, a derivative $\operatorname{del}(3)(\mathrm{A} 3 \mathrm{C}), \quad$ a trisomy $6, \quad$ and a derivative $\operatorname{der}(14) \mathrm{t}(13 ; 14)(14 \mathrm{pter} \rightarrow 14 \mathrm{D} 1:: 14 \mathrm{~B} \rightarrow 14 \mathrm{D} 1:: 13 \mathrm{~A} 3 \rightarrow 13$ qter $)$. Conclusion: It could be shown, that MMT 060562 is most similar to human breast cancer of basal-like tumor type. Thus, this cell line can serve as a model for a very early breast cancer stage and thus closes a gap in the yet available cell lines.
\end{abstract}

Keywords: breast cancer (BC); MMT 060562 murine cell line; murine multicolor banding (mcb)

For citation: Azawi S, Barf LM, Liehr T. First molecular cytogenetic characterization of the MMT 060562 murine breast cancer cell line. Research Results in Biomedicine. 2021;7(1):4-14. DOI: 10.18413/2658-6533-2020-7-1-0-1 
Introduction. In female breast cancer (BC), being a major leading cause of human cancer death, survival chance varies still tremendously, depending on many factors like awareness, preventive programs, diagnostic regimens, and possibilities to treat this disease [1]. The incidence of this malignancy is furthermore influenced by such factors as average life expectancy in the country the person is derived from, life style, individual estrogenlevels, number of children of the woman, and family history of cancer, including adverse gene mutations $[1,2]$. As $\mathrm{BC}$ is heterogenic, it is divided into subtypes according to morphology, molecular profiles, and specific biomarker expression [3]. Accordingly, various subtypes may have different prognoses, clinical outcomes, and maybe in need of specific treatment regimens $[3,4]$. Biomarkers studied to perform BC subclassifications may include oncogene and tumor suppressor gene expression levels, as well as that of other geneproducts, like estrogen-, progesterone-, human epidermal growth factor-2- (HER-2/ ERBB2) and epidermal growth factor-receptor, or cytokeratin 5 or nuclear protein Ki67 $[5,6]$. Thus, BC may be classified in (a) luminal Alike, (b) luminal B-like (HER2-positive and HER2-negative), (c) HER2-overexpressing, and (d) triple-negative subtypes [3, 6]. Furthermore, liquid biopsy plays an increasingly important role in BC follow-up [7].

Various treatment regimens for $\mathrm{BC}$ subtypes are available $[6,8]$, however, severe side effects cannot be excluded in many of these approaches. Also, aggressive courses of disease and limitations in $\mathrm{BC}$ treatment are not unusual [9]. Therefore, research on BC-biology, as well as for new treatment strategies is imperative [10], which are undertaken in cell cultures based on murine BC cell lines [5].

The MMT 060562 murine BC-cell line, also referred to as MMT060562 or MMT060562, has been applied in about 2 dozen studies (see [11]), and, as most of other such cell lines [12], still been not characterized in detail genetically. According to ATCC, this cell line was established in 1962 [13] as being derived from a hybrid female C57BL/6xAf mouse as a spontaneous malignant neoplasm of the mouse mammary gland [14]. To the best of our knowledge the karyotype of this cell line was never published before, however, according to ATCC, MMT 060562 has a modal number of 40 chromosomes with a range of 36 to 81 , and a stem line number being diploid [13], while ECAAC gives a description that the cell line is diploid with $2 \mathrm{n}=$ 40 [14]. To close the gap in the literature, here we present the first molecular cytogenetic characterization of the MMT 060562 cell line.

\section{Material and Methods}

Cell line. The MMT 060562 cell line was purchased from the American Type Culture Collection (ATCCR CCL-51'TM; Wesel Germany) and grown adherently according to the company's instructions: the cells were cytogenetically worked up as previously described [12].

Molecular cytogenetics. FISH was done as previously reported [15] applying whole chromosome paints ("SkyPaintTM DNA Kit M-10 for Mouse Chromosomes", Applied Spectral Imaging, Edingen-Neckarhausen, Germany) for multicolor-FISH (mFISH), and murine chromosome-specific multicolor banding (mcb) probe mixes for FISH-banding [16]. At least 30 metaphases were analyzed for each probe set (Zeiss Axioplan microscopy, equipped with ISIS software (MetaSystems, Altlussheim, Germany).

Data analyses. Imbalances and breakpoints of MMT 060562 were determined according to mcb data and aligned to human homologous regions using the Ensembl and the UCSC Genome Browser, as previously described [12]. The obtained data were compared to genetic changes known from human BCs as previously done [5].

Ethics Statement. According to the Ethical Committee (medical faculty) and the Animal Experimentation Commission of the Friedrich Schiller University, there are no ethical agreements necessary for studies involving murine tumor cell lines like MMT 060562 .

Results. MMT 060562 is a cell line with nearly stable diploid karyotype, only few single cell aberrations were present, which are not reported here. The aberrations detected 
could be divided in two clones, with clone 2 having three sub-clones.

- Clone 1 can be considered as the ancestor and has a completely normal murine karyotype representing $42 \%$ of the studied metaphases; karyotype: 40,XY.

- Clone 2, falling in three subclones, has as typical aberration in common an additional chromosome 6:

- clone 2a showed a trisomy of chromosome 6 and an inversion in a chromosome $2(11.3 \%$ of the cells); karyotype: 41,XY,inv(2)(C3E5), +6;

- clone 2b1 (28.5\% of the cells) acquired a complicated aberration involving chromosomes 13 and 14;
41,XY,+6,der(14)t(13;14)(14pter $\rightarrow$ 14D1::14 $\mathrm{B} \rightarrow 14 \mathrm{D} 1:: 13 \mathrm{~A} 3 \rightarrow 13 \mathrm{qter})$;

- clone $2 b 2$ (18.2\% of the cells) acquired an additional aberration involving chromosomes 2 and 17 and showed the karyotype

40,XY,dic(2;17)(A1A1), del(3)(A3C),+6,der(1 4)t(13;14)(14pter $\rightarrow 14 \mathrm{D} 1:: 14 \mathrm{~B} \rightarrow 14 \mathrm{D} 1:: 13 \mathrm{~A} 3$ $\rightarrow$ 13qter) (Fig. 1).

FISH-data translated to $\mathrm{CGH}$-data is summarized in Table 1 and Fig. 2A. An insilico translation of those results to the human genome identified the corresponding homologous region in the human genome (Table 1, Fig. 2B).

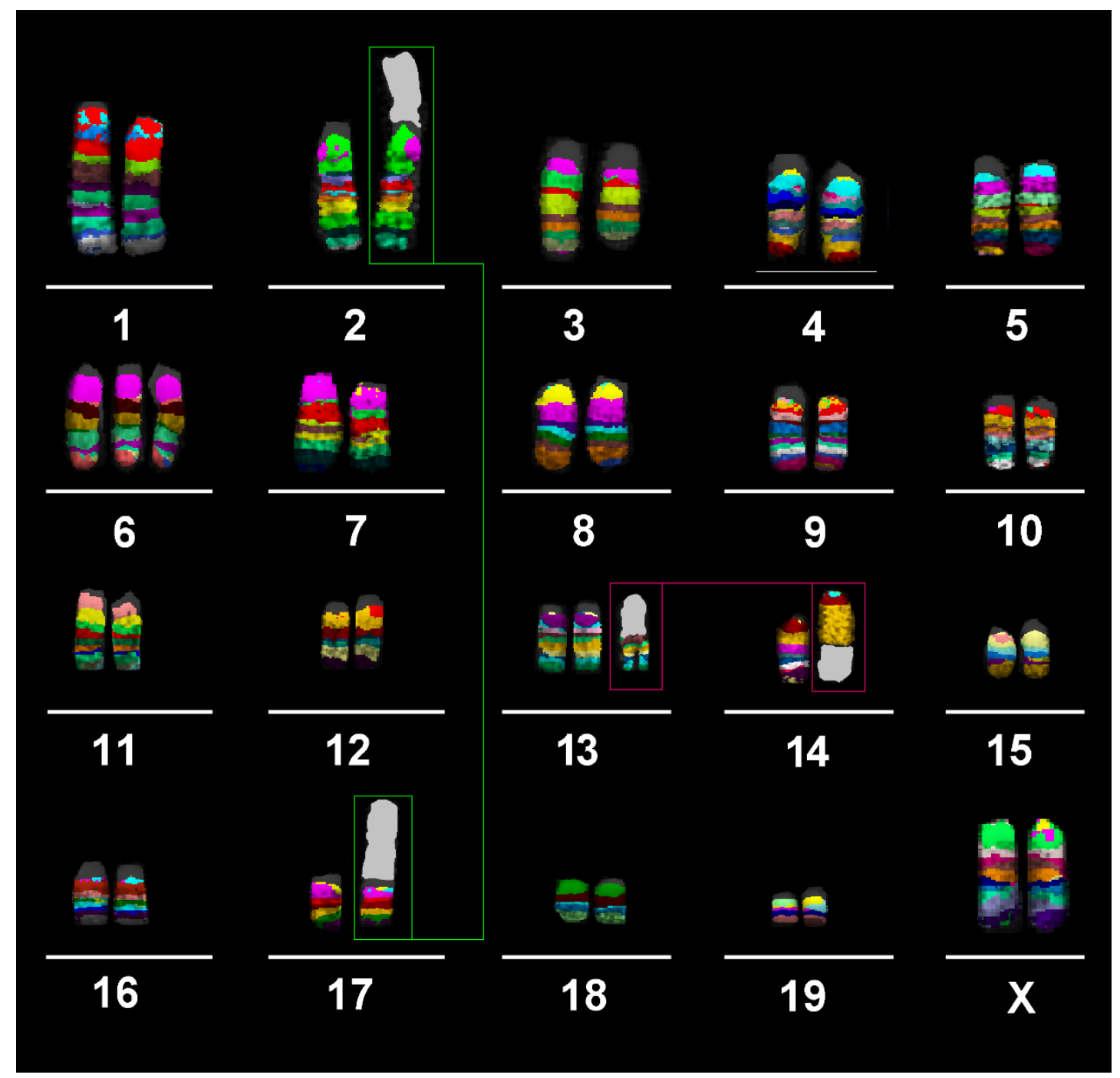

Fig. 1. Murine multicolor banding (mcb) was applied on chromosomes of the MMT 060562 cell line - here the result for clone $2 \mathrm{~b} 2$ is shown. This figure depicts the summary of 20 chromosomespecific FISH-experiments as typical pseudocolor banding. Derivative chromosomes consisting of different chromosomes are highlighted by frames and shown twice in this summarizing karyogram. 
Beginning of Table 1

Homologous regions of the MMT 060562 mouse cell line CNVs, translated to human

\begin{tabular}{|c|c|c|}
\hline Mouse & Human & Type of CNV \\
\hline 2A1-A3 & 10p12.1 & gain \\
\hline $2 \mathrm{~A} 3$ & $2 q 22.2-q 13$ & \\
\hline $2 \mathrm{~A} 3-\mathrm{B}$ & $9 q 33.2-q 34.3$ & \\
\hline 2B-D & 2q22.1-q32.1 & \\
\hline 2D-E3 & $11 \mathrm{p} 14.2-\mathrm{q} 12.1$ & \\
\hline 2E3-F1 & $15 \mathrm{q} 13.3-\mathrm{q} 21.2$ & \\
\hline $2 \mathrm{~F} 1$ & $2 \mathrm{p} 11.2-\mathrm{q} 11.2$ & \\
\hline $2 \mathrm{~F} 1$ & $2 q 13$ & \\
\hline $2 \mathrm{~F} 1-\mathrm{H} 4$ & 20p13-q13.33 & \\
\hline 6A1 & 7p22.1-p21.3 & gain \\
\hline $6 \mathrm{~A} 1$ & $7 \mathrm{q} 21.2-\mathrm{q} 21.3$ & \\
\hline 6A1-B2 & 7q31.1-q36.1 & \\
\hline $6 \mathrm{~B} 2$ & 7q36.1 & \\
\hline 6B2-B3 & 7p15.3-p14.3 & \\
\hline 6B3-C1 & $4 q 22.1-q 22.3$ & \\
\hline $6 \mathrm{C} 1$ & $4 \mathrm{q} 27$ & \\
\hline $6 \mathrm{C} 1$ & $1 \mathrm{p} 31.3$ & \\
\hline 6C1-D1 & 2p13.3-p11.2 & \\
\hline 6D1 & 3p25.2-p25.1 & \\
\hline 6D1 & $3 \mathrm{q} 21.2-\mathrm{q} 21.3$ & \\
\hline 6D1-E & 3p14.1-p12.3 & \\
\hline 6E1-E3 & $3 \mathrm{p} 26.3-\mathrm{p} 25.2$ & \\
\hline $6 \mathrm{E} 3$ & 3q21.3-q22.1 & \\
\hline 6E3-F1 & $10 \mathrm{q} 11.21-\mathrm{q} 11.22$ & \\
\hline $6 \mathrm{~F} 1$ & 22q11.1-q11.21 & \\
\hline 6F1-F3 & 12p13.33-p13.31 & \\
\hline $6 \mathrm{~F} 3$ & $12 \mathrm{p} 11.21$ & \\
\hline $6 \mathrm{~F} 3$ & $12 \mathrm{p} 11.21$ & \\
\hline 6F3-G3 & 12p13.31-p11.21 & \\
\hline 13A3-A5 & $6 \mathrm{p} 25.3-\mathrm{p} 23$ & gain \\
\hline $13 \mathrm{~A} 5$ & $6 \mathrm{p} 23-\mathrm{p} 22.3$ & \\
\hline 13A5-B1 & $9 q 22.1-q 22.32$ & \\
\hline 13B1 & $5 \mathrm{q} 31.1-\mathrm{q} 31.2$ & \\
\hline 13B1 & $5 \mathrm{q} 35.2-\mathrm{q} 35.3$ & \\
\hline 13B1-B2 & $9 \mathrm{q} 21.32-\mathrm{q} 21.33$ & \\
\hline 13B3 & $8 \mathrm{q} 22.1$ & \\
\hline 13B3 & $9 \mathrm{p} 11.2$ & \\
\hline 13B3 & $9 \mathrm{p} 13.1$ & \\
\hline 13B3 & $9 q 12-q 13$ & \\
\hline 13B3 & $9 \mathrm{q} 22.32-\mathrm{q} 22.33$ & \\
\hline 13B3-C1 & 5p15.33-p15.31 & \\
\hline $13 \mathrm{C} 1-\mathrm{C} 3$ & $5 q 14.3-q 15$ & \\
\hline 13C3-D1 & $5 q 13.2-q 14.3$ & \\
\hline 13D1-D2 & 5q11.1-q13.2 & \\
\hline $13 \mathrm{D} 2$ & $5 \mathrm{p} 12$ & \\
\hline $13 \mathrm{D} 2$ & $1 \mathrm{p} 11.2$ & \\
\hline
\end{tabular}


End of Table 1

Homologous regions of the MMT 060562 mouse cell line CNVs, translated to human

\begin{tabular}{|c|c|c|}
\hline Mouse & Human & Type of CNV \\
\hline 14B & $3 \mathrm{p} 25.1$ & gain \\
\hline 14B & 10q11.2-q11.23 & \\
\hline $14 \mathrm{C} 1$ & $14 \mathrm{q} 22.1-\mathrm{q} 23.1$ & \\
\hline $14 \mathrm{C} 1-\mathrm{C} 3$ & $14 q 11.2-q 12$ & \\
\hline $14 \mathrm{C} 3$ & $13 q 12.11$ & \\
\hline $14 \mathrm{C} 3$ & $13 q 12.12$ & \\
\hline 14C3-D1 & $13 \mathrm{q} 14.2$ & \\
\hline 14D1 & $13 q 12.12$ & \\
\hline 14D1 & $13 q 14.2-q 14.3$ & \\
\hline 14D1 & $13 \mathrm{q} 12.13$ & \\
\hline 17A1 & $6 \mathrm{q} 25.2-\mathrm{q} 25.3$ & gain \\
\hline 17A1 & $6 q 25.3-q 27$ & \\
\hline 17A1 & $6 \mathrm{q} 27$ & \\
\hline 17A1-A2 & $6 q 27$ & \\
\hline 17A2-A3 & $5 q 15-q 21.1$ & \\
\hline $17 \mathrm{~A} 3$ & $5 q 35.1$ & \\
\hline $17 \mathrm{~A} 3$ & $6 \mathrm{p} 21.32-\mathrm{p} 21.2$ & \\
\hline $17 \mathrm{~A} 3$ & $16 \mathrm{p} 13.3$ & \\
\hline 17A3-B1 & $21 \mathrm{q} 22.3$ & \\
\hline 17B1 & $6 \mathrm{p} 22.1-\mathrm{p} 21.32$ & \\
\hline 17B1 & $19 \mathrm{p} 13.12$ & \\
\hline 17B1 & $19 \mathrm{p} 13.2$ & \\
\hline 17B2-C & 6p21.2-p12.3 & \\
\hline $17 \mathrm{C}$ & $2 \mathrm{q} 12.2-\mathrm{q} 12.3$ & \\
\hline $17 \mathrm{C}$ & $3 \mathrm{p} 25.1-\mathrm{p} 24.3$ & \\
\hline 17D & 19p13.3 & \\
\hline 17D-E1 & $5 \mathrm{q} 21.1-\mathrm{q} 22.1$ & \\
\hline 17E1 & 18p11.32-p11.22 & \\
\hline 17E1-E5 & 2p23.2-p16.3 & \\
\hline 17E5 & $2 \mathrm{p} 16.3-\mathrm{p} 16.2$ & \\
\hline 17E5 & $18 \mathrm{p} 11.32$ & \\
\hline $3 \mathrm{~A} 3$ & $3 q 26.2-q 26.32$ & loss \\
\hline $3 \mathrm{~A} 3-\mathrm{B}$ & $3 q 26.32-q 27.1$ & \\
\hline $3 B$ & $9 \mathrm{p} 11.2$ & \\
\hline $3 \mathrm{~B}$ & 9p12 & \\
\hline $3 B$ & 9q13 & \\
\hline $3 \mathrm{~B}-\mathrm{C}$ & $4 q 27-q 31.1$ & \\
\hline 14D1 & $8 \mathrm{p} 23.1$ & loss \\
\hline 14D1-D2 & 8p21.3-p12 & \\
\hline 14D2-D3 & 13q14.11-q14.2 & \\
\hline 14D3-E4 & 13q14.3-q33.1 & \\
\hline $2 \mathrm{~A} 1$ & n.a. & breakpoint \\
\hline $2 \mathrm{C} 3$ & $2 q 23$ & breakpoint \\
\hline $2 \mathrm{E} 5$ & $15 \mathrm{q} 15$ & breakpoint \\
\hline $3 \mathrm{~A} 3$ & $3 q 26.2$ & breakpoint \\
\hline $3 \mathrm{C}$ & $4 q 31.1$ & breakpoint \\
\hline 14D1 & $13 \mathrm{q} 14.1$ & breakpoint \\
\hline $17 \mathrm{~A} 1$ & n.a. & breakpoint \\
\hline
\end{tabular}




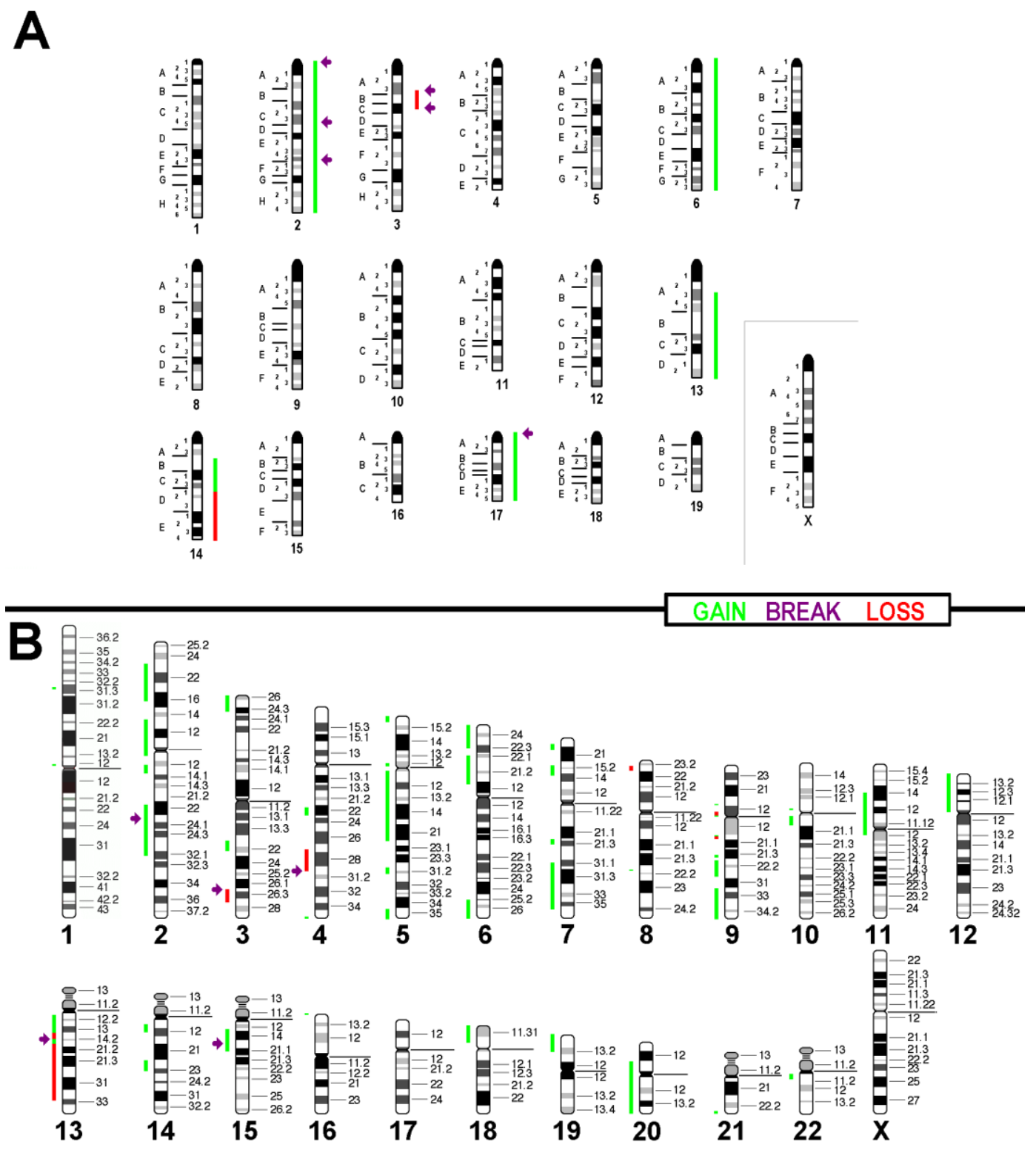

Fig. 2. Copy number variations detected in the MMT 060562 cell line are summarized here with respect to a diploid-basic karyotype. Gains are shown as green bars and losses are red, and breaks are registered as arrows. (A) Imbalances found in the cell line depicted along a murine chromosome set; (B) Results translated and projected along the human chromosome set.

Comparison with literature. The corresponding homologous regions of the MMT 060562 cell line compared with the common imbalances in related to human $\mathrm{BC}[5,17,18]$ revealed copy number variations in 9 of 21 regions $(43 \%)$ known to harbor oncogenes and tumor suppressor genes (Table 2). The here reported breakpoints of MMT 060562 compared to chromosomal breaks of human $\mathrm{BC}$ presented a congruency of $6 \%$, only (Table 3). The genetic alterations in the cell line correlated with the molecular subtype for human $\mathrm{BC}$ as shown in Table 4. The results revealed the best correspondence between MMT 060562 and human BC subtype basallike tumors $(18 \%)$. 
Oncogenes and tumor suppresser genes of importance in $\mathrm{BC}$ according to the literature $[17,18]$ and their involvement in gains or loss of copy numbers in the studied cell line

\begin{tabular}{|c|c|c|}
\hline $\begin{array}{c}\text { Oncogenes and tumor suppressor } \\
\text { genes }\end{array}$ & Gene loci in human & MMT 060562 \\
\hline NRAS & $1 \mathrm{p} 22$ or $\mathrm{p} 13$ & no CNV \\
\hline$M S H 2$ & $2 \mathrm{p} 22$ & gain \\
\hline$R A F 1$ & $3 \mathrm{p} 25$ & gain \\
\hline$R A R \beta 2$ & 3 p24 & no CNV \\
\hline MLH1 & $3 \mathrm{p} 21$ & no CNV \\
\hline$A P C$ & $5 q 21$ & gain \\
\hline$M Y B$ & $6 q 22-q 23$ & no CNV \\
\hline$I G F I I-R$ & $6 q 26$ & gain \\
\hline$M Y C$ & $8 q 24$ & no CNV \\
\hline$C D K N 2 A(p 16 I N K 4)$ & 9 p21 & no CNV \\
\hline PTEN & $10 q 23$ & no CNV \\
\hline HRAS & $11 \mathrm{p} 15.5$ & no CNV \\
\hline$C C N D 1$ & $11 q 13$ & no CNV \\
\hline INT2 & $11 q 13$ & no $\mathrm{CNV}$ \\
\hline$A T M$ & $11 q 22$ & no CNV \\
\hline$C D K N 1 B(p 27 k i p 1)$ & $12 \mathrm{p} 13$ & gain \\
\hline KRAS2 & $12 \mathrm{p} 12.1$ & gain \\
\hline$B R C A 2$ & $13 q 12$ & gain \\
\hline$R B 1$ & $13 q 14.2$ & gain \\
\hline CDH1 (E-cadherin) & $16 q 22$ & no CNV \\
\hline TP53 (p53) & $17 \mathrm{p} 13$ & no CNV \\
\hline$E R B B 2$ & $17 q 21$ & no CNV \\
\hline$B R C A 1$ & $17 q 21$ & no CNV \\
\hline SERPINB5 (maspin) & $18 \mathrm{q} 21$ & no CNV \\
\hline STK11 (LKB1) & $19 \mathrm{p} 13$ & gain \\
\hline \multicolumn{2}{|c|}{ SUM of concordance in CNVs of potentially affected regions } & $9 / 21$ \\
\hline
\end{tabular}

Note: CNV - copy number variant 
Breakpoints in MMT 060562 compared to the observed acquired breaks in human BCs according to the literature [5]. Concordances with human breakpoints are highlighted in bold

\begin{tabular}{|c|c|c|}
\hline Breakpoint acc. to human genome & Human BC & MMT 060562 \\
\hline $1 \mathrm{p} 33$ & + & - \\
\hline $1 \mathrm{q} 25.3$ & + & - \\
\hline $2 \mathrm{p} 23$ & - & + \\
\hline $2 \mathrm{q} 31.3$ & + & - \\
\hline $3 p 26.1$ & + & $(+)$ \\
\hline $3 \mathrm{p} 12.3$ & + & - \\
\hline $3 q 21.3$ & + & - \\
\hline $4 q 22.3$ & + & - \\
\hline $4 q 26$ & + & - \\
\hline $4 \mathrm{q} 31.23$ & + & $(+)$ \\
\hline $5 \mathrm{p} 14.2$ & + & - \\
\hline $5 q 13.2$ & + & - \\
\hline $5 q 14.3$ & + & - \\
\hline 6q12 & + & - \\
\hline $8 \mathrm{q} 23.3$ & + & - \\
\hline $8 \mathrm{q} 24.22$ & + & - \\
\hline $9 \mathrm{p} 24.2$ & + & - \\
\hline $9 \mathrm{p} 21$ & + & - \\
\hline $10 \mathrm{p} 11.21$ & + & - \\
\hline $11 \mathrm{p} 15.5$ & + & - \\
\hline $12 \mathrm{q} 12.1$ & + & - \\
\hline $12 \mathrm{q} 24.31$ & + & - \\
\hline $13 \mathrm{q} 21.2$ & + & - \\
\hline $13 \mathrm{q} 14.1$ & - & + \\
\hline $14 q 32$ & + & - \\
\hline $15 q 15$ & - & + \\
\hline $16 q 13.3$ & + & - \\
\hline $17 \mathrm{p} 12$ & + & - \\
\hline $17 q 21$ & + & - \\
\hline 19p13.1 & + & - \\
\hline $20 \mathrm{q} 13.3$ & + & - \\
\hline $22 \mathrm{q} 12.2$ & + & - \\
\hline \multicolumn{2}{|c|}{ SUM of concordance } & $2 / 32$ \\
\hline
\end{tabular}


Table 4

Copy number changes associated with molecular subtypes of human BC, according to [19], with the copy number variants (CNVs) in the MMT 060562 cell line. Concordances with human CNVs (in italics) are highlighted in bold

\begin{tabular}{|c|c|c|}
\hline DNA changes in BC Subtypes & Human BC & MMT 060562 \\
\hline \multicolumn{3}{|l|}{ HER2+ } \\
\hline 17q11.1 12 & gain & no $\mathrm{CNV}$ \\
\hline $17 \mathrm{q} 21.31 \sim 23.2$ & gain & no $\mathrm{CNV}$ \\
\hline \multicolumn{2}{|c|}{ SUM of concordance } & $0 / 2$ \\
\hline \multicolumn{3}{|l|}{ Basal-like tumors } \\
\hline $4 \mathrm{p} 15.31$ & loss & no $\mathrm{CNV}$ \\
\hline $5 q 12.3 \sim 13.2$ & loss & gain \\
\hline $5 q 33.1$ & loss & no CNV \\
\hline $6 \mathrm{p} 12.3$ & gain & gain \\
\hline $6 \mathrm{p} 21.1 \sim 23$ & gain & gain \\
\hline 8q24.21 24.22 & gain & no $\mathrm{CNV}$ \\
\hline 10p12.33 14 & gain & no $\mathrm{CNV}$ \\
\hline $10 \mathrm{q} 23.33$ & loss & no $\mathrm{CNV}$ \\
\hline $12 \mathrm{q} 13.13 \sim 13.3$ & loss & no CNV \\
\hline $15 \mathrm{q} 15.1$ & loss & gain \\
\hline $15 \mathrm{q} 21.1$ & loss & gain \\
\hline \multicolumn{2}{|c|}{ SUM of concordance } & $2 / 11$ \\
\hline \multicolumn{3}{|l|}{ Luminal A } \\
\hline $1 \mathrm{q} 21.3 \sim 44$ & gain & no $\mathrm{CNV}$ \\
\hline $16 \mathrm{p} 13.12 \sim 13.13$ & gain & no $\mathrm{CNV}$ \\
\hline 16q11.2 13 & loss & no $\mathrm{CNV}$ \\
\hline $16 \mathrm{q} 22.1-24.1$ & loss & no $\mathrm{CNV}$ \\
\hline \multicolumn{2}{|c|}{ SUM of concordance } & $0 / 4$ \\
\hline \multicolumn{3}{|l|}{ Luminal B } \\
\hline $1 \mathrm{p} 31.3$ & loss & gain \\
\hline $8 \mathrm{p} 21.2 \sim 23.1$ & loss & no $\mathrm{CNV}$ \\
\hline $17 \mathrm{q} 23.2$ & gain & no $\mathrm{CNV}$ \\
\hline \multicolumn{2}{|c|}{ SUM of concordance } & $0 / 3$ \\
\hline
\end{tabular}

Note: no CNV - no copy number variant

Discussion. Heterogeneity of $\mathrm{BC}$ is one of the reasons that its biology is overall still poorly understood. Correspondingly, basic research and studies testing new potential therapeutics are necessary [9; 20]. MMT 060562 is a murine BC cell line yet not characterized cytogenomically in detail. Thus, its reluctant use in research studies, according to PUBMED [11] only 20 papers are published using this cell line, here we did the first detailed molecular cytogenetic study to close this gap. The same approach as previously undertaken for several other murine cell lines was done for MMT $060562[5,12,15,16$, 21-23].

The MMT 060562 cell line presents a normal karyotype in $\sim 40 \%$ of the studied cells, which is surprising for an almost 60year-old cell line. Most likely it would be an ideal candidate to be studied by sequencing, to find submicroscopic mutations leading cells on the path towards BC-malignization. Also it is striking that since its establishment MMT 060562 cells did not tertaploidize, as reported mainly for human cell lines [24] and $\sim 50 \%$ of murine tumour cell lines $[5,12,15$, 
16, 21-23]. To the best of our knowledge, the MMT 060562 cell line is the less chromosomal aberrant malignant cell line ever reported. However, it is definitely a cell line, which induced tumors in nude mice [25].

Conclusion. Overall and in conclusion, the MMT 060562 cell line is a very interesting model system for early human BC, which should be studied in more detail and applied in corresponding studies for new therapeutica.

\section{Financial support}

Supported by grant \# 2013.032.1 of the Wilhelm Sander-Stiftung.

\section{Conflict of interests}

The authors have no conflict of interest to declare.

\section{References}

1. Shah R, Rosso K, Nathanson SD. Pathogenesis, prevention, diagnosis and treatment of breast cancer. World Journal of Clinical Oncology. 2014;5(3):283-298. DOI: https://doi.org/10.5306/wjco.v5.i3.283

2. Sun YS, Zhao Z, Yang ZN, et al. Risk factors and preventions of breast cancer. International Journal of Biological Sciences. 2017;13(11):1387-1397. DOI: https://doi.org/10.7150/ijbs.21635

3. Januškevičienė I, Petrikaitė V. Heterogeneity of breast cancer: The importance of interaction between different tumor cell populations. Life Sciences. 2019;239(1):117009. DOI: https://doi.org/10.1016/j.lfs.2019.117009

4. Rouzier R, Perou CM, Symmans WF, et al. Breast cancer molecular subtypes respond differently to preoperative chemotherapy. Clinical Cancer Research. 2005;11(16):5678-5685. DOI: https://doi.org/10.1158/1078-0432.CCR-04-2421

5. Azawi S, Liehr T, Rincic M, et al. Molecular cytogenomic characterization of the murine breast cancer cell lines C-127I, EMT6/P and TA3 Hauschka. International Journal of Molecular Sciences. 2020;21(13):4716. DOI: https://doi.org/10.3390/ijms21134716

6. Kikuchi-Koike R, Nagasaka K, Tsuda $\mathrm{H}$, et al. Array comparative genomic hybridization analysis discloses chromosome copy number alterations as indicators of patient outcome in lymph node-negative breast cancer. BMC Cancer. 2019;19(1):521. DOI:
7. Alimirzaie S, Bagherzadeh M, Akbari MR. Liquid biopsy in breast cancer: A comprehensive review. Clinical Genetics. 2019;95(6):643-660.

DOI: https://doi.org/10.1111/cge.13514

8. Yersal O, Barutca S. Biological subtypes of breast cancer: Prognostic and therapeutic implications. World Journal of Clinical Oncology. 2014;5(3):412-424.

DOI: http://dx.doi.org/10.5306/wjco.v5.i3.412.

9. Feng $Y$, Spezia $M$, Huang $S$, et al. Breast cancer development and progression: Risk factors, cancer stem cells, signaling pathways, genomics, and molecular pathogenesis. Genes and Diseases. 2018;5(2):77-106. DOI: https://doi.org/10.1016/j.gendis.2018.05.001

10. Raihan J, Ahmad U, Yong YK, et al. Regression of solid breast tumours in mice by Newcastle disease virus is associated with production of apoptosis relatedcytokines. BMC Cancer. 2019;19(1):315. DOI: https://doi.org/10.1186/s12885-019-5516-5

11.PUBMED [Internet]. Seach for MMT 060562, MMT060562 or MMT-060562 [cited 2021 Jan 22]. Available from: https://pubmed.ncbi.nlm.nih.gov

12. Rhode H, Liehr T, Kosyakova N, et al. Molecular cytogenetic characterization of two murine colorectal cancer cell lines. OBM Genetics. 2018;2(3):1803037. DOI: https://doi.org/10.21926/obm.genet.1803037

13. ATCC [Internet]. [cited 2021 Jan 22]. Available from: https://www.lgcstandardsatcc.org/Products/All/CCL-

51.aspx?geo_country=de\#history

14.ECACC [Internet]. [cited 2021 Jan 22]. Available from: https://www.pheculturecollec-

tions.org.uk/products/celllines/generalcell/detail.js p?refId $=90111911 \&$ collection $=$ ecacc $\_$gc

15. Kubicova E, Trifonov V, Borovecki F, et al. First molecular cytogenetic characterization of murine malignant mesothelioma cell line AE17 and in silico translation to the human genome. Current Bioinformatics. 2017;12(1):11-18. DOI: https://doi.org/10.2174/157489361166616060616 4459

16.Leibiger C, Kosyakova N, Mkrtchyan H, et al. First molecular cytogenetic high resolution characterization of the NIH $3 \mathrm{~T} 3$ cell line by murine multicolor banding. Journal of Histochemistry and Cytochemistry. 2013;61(4):306-312. DOI: https://doi.org/10.1369/0022155413476868 
17.Hall JM, Zuppan PJ, Anderson LA, et al. Oncogenes and human breast cancer. American Journal of Human Genetics. 1989;44(4):577-584.

18.Lebok P, Roming M, Kluth M, et al. p16 overexpression and 9p21 deletion are linked to unfavorable tumor phenotype in breast cancer. Oncotarget. 2016;7(49):81322-81331. DOI: https://doi.org/10.18632/oncotarget.13227

19.Horlings HM, Lai C, Nuyten DS, et al. Integration of DNA copy number alterations and prognostic gene expression signatures in breast cancer patients. Clinical Cancer Research. 2010;16(2):651-663. DOI: https://doi.org/10.1158/1078-0432.CCR-09-0709

20. Ye Y, Qiu TH, Kavanaugh C, et al. Molecular mechanisms of breast cancer progression: Lessons from mouse mammary cancer models and gene expression profiling. Breast Disease. 2004;19(1):69-82.

DOI: https://doi.org/10.3233/bd-2004-19109

21.Guja K, Liehr T, Rincic M, et al. Molecular cytogenetic characterization identified the murine B-cell lymphoma cell line A-20 as a model for sporadic Burkitt's lymphoma. Journal of Histochemistry and Cytochemistry. 2017;65(11):669-677. DOI: https://doi.org/10.1369/0022155417731319

22.Steinacker R, Liehr T, Kosyakova N, et al. Molecular cytogenetic characterization of two murine cancer cell lines derived from salivary gland. Biological Communications. 2018;63(4):243-255. DOI: https://doi.org/10.21638/spbu03.2018.403

23. Wahlbul E, Liehr T, Rincic M, et al. Cytogenomic characterization of three murine malignant mesothelioma tumor cell lines. Molecular Cytogenetics. 2020;13(1):43. DOI: https://doi.org/10.1186/s13039-020-00511-4
24.Tan Z, Chu DZV, Chan YJA, et al. Mammalian cells undergo endoreduplication in response to lactic acidosis. Scientific Reports. 2018;8(1):2890. DOI: https://doi.org/10.1038/s41598-018-20186-7

25. Ono K, Akatsu T, Kugai N, et al. The effect of deletion of cyclooxygenase-2, prostaglandin receptor EP2, or EP4 in bone marrow cells on osteoclasts induced by mouse mammary cancer cell lines. Bone. 2003;33(5):798-804. DOI: https://doi.org/10.1016/s8756-3282(03)00264-3

Received 9 January 2021

Revised 12 February 2021

Accepted 14 February 2021

\section{Information about the authors}

Shaymaa Azawi, Researcher at the Molecular Cytogenetics Laboratory, Jena University Hospital, Friedrich Schiller University, Institute of Human Genetics, Jena, Germany, E-mail: shayma.alazawi@yahoo.com, ORCID: 0000-0001-8681-1768.

Lisa-Marie Barf, Researcher at the Molecular Cytogenetics Laboratory, Jena University Hospital, Friedrich Schiller University, Institute of Human Genetics, Jena, Germany, E-mail: Lisa-Marie.Barf@uni-jena.de, ORCID: 0000-0001-7535-2690.

Thomas Liehr, PhD, PD, Head of Molecular Cytogenetics Laboratory, Jena University Hospital, Friedrich Schiller University, Institute of Human Genetics, Jena, Germany, E-mail: Thomas.Liehr@med.uni-jena.de, ORCID: 0000-0003-1672-3054. 